\title{
Achieving everlasting happiness in life through Bhagawad Gita
}

\begin{abstract}
Modern world has witnessed a drastic increase in human sufferings, from dissatisfaction, anxiety and depression. To lead a happy and satisfied life, rational and logical spiritual awakening is the need of the hour. Bhagawad Gita ("The Song of God), the ancient Hindu scripture, dictates the most powerful wisdom to lead a skillful life and endows solutions to end every human suffering. So, implementing Bhagawad Gita in our life will grant us everlasting happiness.
\end{abstract}

Keywords: human sufferings, bhagawad gita, hindu scripture, happiness
Volume II Issue 5 - 2020

Anurag Protim Das

Department of Life Sciences, Dibrugarh University, India

Correspondence: Anurag Protim Das, Department of Life Sciences, Dibrugarh University, India, Email anuragprotim.99@gmail.com

Received: October 8, 2020 | Published: October 13, 2020

\section{Editorial}

Since last few decades the world is changing in all the frontiers at a rapid pace. With the advent of modern sciences \& technology, life has become much easier in comparison to the past. We are dwelling in an era of information technology, with instant accessibility to creative and instant pleasure attributes. It has been easier to explore the world, as humanity's library of knowledge in everyone's reach. The modern world has been transformed miraculously into a heavenly replica, yet a larger mass of people finds oneself trapped under constrain. The advent of many modern wonders gave birth to uniquely modern forms of sufferings and psychological distress, from anxiety towards a state of depression.

In modern times, supernormal vices with massive addictive potential, has steadily became a part of our normal life. From life threatening drugs to unhealthy junk foods, to mind polluting porn to video games, and attachment to social media, for temporary pleasure has invaded our life. Needless to depict the environment or the ecosystem, we are currently swimming more precisely drowning for temporary pleasure without ethics. No wonder, why majority of us feel dissatisfied, anxious and always in search of next twitch to feel instant high. Entrapped in a myriad of stimulation and distractions of super normality attributes, for temporary pleasure, we are detaching from logical reasoning behind attaining satisfaction, from serenity and most importantly from oneself both intellectually and spiritually. The majority of sufferings arise due to attachment of physical pleasures which does not last forever, as life itself have a limited existence. Spiritual, logical and scientific awakening can only equip you with the right navigation to transverse the labyrinth of modern life more skillfully and, find greater and higher purpose and meaning of life.

About 5000 years ago, from the battlefield known as Kurukshetra, which occurred between Pandavas and Kauravas for establishing dharma - the justice of reality based on right thought and action. The war was between family members, friends and revered teachers, ready for bloodshed for the call of duty. The famous archer Arjuna, the lead hero of this story was caught in a moral dilemma. Inspite of being sure, that he was on the side of dharma. He couldn't convince himself to kill his own brothers, friends, uncles for establishment of dharma, so, Arjuna was about to quit fighting the battle. Arjuna was blessed as Lord Krishna; an embodiment of dharma was his charioteer, who confronted him. A divine conversation took place between Lord Krishna and Arjuna for investigation of truth, and eventually leads to discovery of the most powerful wisdom to live at the highest level. And this conversation came to be known as Bhagawad Gita ("The Song of God). Bhagawad Gita, since 5000 years has proven to be precise way of leading a skillful life at the highest level. One of the phrases from Bhagawad Gita (written in Sanskrit language) is as follows (Chapter 5, Sloka no. 22);

\section{ye hi samsparsa ja bhoga duhkha-yonaya eva te}

\section{ady-antavantah kaunteya na tesu ramate budhah}

Which means an intelligent person detaches oneself from material senses, which are the core sources of misery. Material pleasures are temporary have smaller span of existence, since the body itself have a temporary existence. A wise man doesn't indulge in any sort of such pleasures of temporary gratification. Rather, a noble soul elevates and develops a higher level of taste in by discarding the lower one. So, an intelligent soul dwells at the levels of intellectuality and spirituality, and detaches from material pleasures. At the intellectual and spiritual level, the bodily needs are minimized and one achieves satisfaction and purification, and as a result enjoys unlimited transcendental bliss.

So, the people who are intelligent, wise or learned transcendentalists stay away from any sort of sense pleasures. They understand that higher addiction towards material pleasures will degrade the quality of life and deprive in attaining the higher meaning of life. So, to lead a happy and satisfied life one should focus on intellectual and spiritual attributes discarding the material or sense pleasures.

\section{Funding}

None.

\section{Acknowledgments}

None.

\section{Conflicts of interest}

The author declares that there is no conflict of interest to declare. 